\title{
3 Research Square \\ Is the Genetic Integrity of Wild Coffea Canephora From Ivory Coast Threatened by Hybridization With Introduced Coffee Trees From Central Africa?
}

\section{GNAPI Diane Estelle}

Université Félix Houphouët-Boigny: Universite Felix Houphouet-Boigny

Desire POKOU ( $\square$ desire.pokou@gmail.com )

Centre National de Recherche Agronomique de Côte d'Ivoire https://orcid.org/0000-0003-4863-6385

\section{LEGNATE Hyacinthe}

Centre National de Recherche Agronomique de Côte d'Ivoire: Centre National de Recherche Agronomique de Cote d'Ivoire

DAPENG Zhang

USDA-ARS Beltsville Agricultural Research Center

Christophe MONTAGNON

RD2Vision

\section{Benoît BERTRAND}

Centre de Coopération Internationale en Recherche Agronomique pour le Développement: CIRAD

Simon-Pierre Assanvo N'GUETTA

Universite Felix Houphouet-Boigny

\section{Research Article}

Keywords: Coffea canephora, Genetic resources, genetic erosion, crop wild relative

Posted Date: November 23rd, 2021

DOI: https://doi.org/10.21203/rs.3.rs-1026879/v1

License: (a) (1) This work is licensed under a Creative Commons Attribution 4.0 International License.

Read Full License 


\section{Abstract}

Canephora coffee is an important source of income and employment, contributing significantly to the economies of many developing countries. This species is split into two genetic groups: Guinean and Congolese. Côte-d'Ivoire is the primary diversification center of the Guinean pool, which offers great potential for genetic improvement. However, genetic erosion of this group is currently a threat in this country because of the massive introduction of Congolese accessions in the previous decades. In this work, we analyzed the progenies of isolated population of $C$. canephora composed of a mix of Guinean and Congolese using SNP markers. The analysis is focus on the male parents' contribution on open pollination progenies. The result shows that the introduction of cultivars from the Congolese gene pool threat the genetic integrity of wild populations of the Guinean gene pool. We recommend that a conservation program be put in place to ensure the entegrity of wild population of $C$. canephora through in situ or ex situ conservation.

\section{Introduction}

Coffee (Coffea sp) is a perennial plant originated from the tropical and intertropical areas of Africa, Comoros, Mascarene Islands (Mauritius and Reunion Island), Asia and Australia (Davis et al. 2006). Coffee trees are split into 125 species, all belonging to the genus Coffea and the family Rubiaceae (Davis et al. 2011). In all producing countries, the economic and social interest of coffee is no longer in question. Indeed, the income generated by its cultivation is close to 173,000 million dollars (US) for the entire coffee value chain (ICO 2018). It is a major export product, with about nine million tons of green coffee produced each year (ICO 2018), and its cultivation covers more than 10 million hectares of cultivable land in 80 countries (FAOSTAT 2019). In addition, coffee production and processing employs over 125 million people in the production chain (Van Der Vossen 2016). In Côte d'Ivoire, the coffee cultivation area represents over 400,000 hectares (FAOSTAT 2018). Coffee therefore presents an important economic and social challenge for producing countries.

Among the 125 described species, Coffea canephora is the main species cultivated because of the favorable environment for its cultivation (Coste 1989). This species is diploid ( $2 n=2 x=22$ ), strictly allogamous and self-incompatible (Berthaud 1986; Devreux et al. 1959; Coulibaly 2002). Phylogenetic studies carried out within the species $C$. canephora, have allowed a structuring into two distinct genetic groups with contrasting morphological traits for architecture, resistance to orange rust, bean size and caffeine content (Berthaud 1986; Leroy et al. 1993 and 1997; Montagnon et al. 2008). These are the early flowering Guinean pool, originating from West Africa, especially in the mountainous west of Ivory Coast and Guinea as the primary center of diversification; and the late flowering Congolese pool, originating in Central Africa (essentially the Congo Basin) and Southern Africa. The Congolese pool is subdivided into two subgroups named SG1 and SG2 (Montagnon et al. 1992).

In order to improve the productivity, numerous accessions from SG1 and SG2 were introduced in Côted'Ivoire at the beginning of coffee cultivation (Berthaud 1986; Montagnon et al. 1992b). Thus, due to the 
contrasting characters of the Guinean and Congolese groups, they were use in a reciprocal recurrent selection breeding scheme (Leroy et al 1993 and 1997; Montagnon 2000). The genetic resources involved in this selection scheme were conserved as ex situ genebanks. Most of these resources are located at the Centre National de Recherche Agronomique (CNRA) station in Divo (Côte d'Ivoire). This gene bank held about 1900 accessions of $C$. canephora, from various origins (Labouisse et al. 2020).

The geographic range and reproductive system of $C$ canephora, as well as the impact of past climates, have resulted in high genetic variability within the species and the formation of unselected populations obtained from seeds from open pollinations (Gomez et al. 2009; Eskes and Leroy 2012). In addition, other factors such as the lack of pollens and female flowers, flowering synchronicity, number and density of trees, and their spatial distributions, act to alter the genetic diversity and structure of natural populations (oddou-Muratorio et al. 2011; Sagnard et al. 2011). In addition, population size and the levels of gene flow in $C$. canephora, may have long-standing effects on the genetic composition of current gene pools in the wild. These threats are to be consider with the impact of climate change (Bunn et al. 2015), bushfires, and heavy deforestation of natural forests in Côte d'Ivoire and Guinea (Brou et al. 2000). Besides, the introduction of the Congolese pool into Côte d'Ivoire has helped foster genetic exchanges with the Guinean group in local plantations (Montagnon et al. 1993). Is the shift between early and late flowering a sufficient barrier to prevent mass pollination of the wild populations by pollens from the cultivated trees?

The objective of this study is to evaluate the impact of the introduction of the Congolese pool on the genetic integrity of the Guinean pool endemic to Côte d'Ivoire, and mostly distributed in natural areas where coffee growing is important.

\section{Material And Methods}

\section{Site of study}

The study was conducted at the research station of the Centre National de Recherche Agronomique (CNRA) located between $5^{\circ} 46^{\prime}$ north latitude and $5^{\circ} 17^{\prime}$ west longitude. The relief is characterized by plains with an altitude of between 100 and $200 \mathrm{~m}$. The soils are ferralitic, deep, acidic and desaturated in exchangeable bases (Kassin et al. 2008). Temperatures range from 28 to $32^{\circ} \mathrm{C}$, with a daily range of 6 to $7^{\circ} \mathrm{C}$. Humidity averages $80 \%$ (N'Guessan 2017). The average rainfall is $1400 \mathrm{~mm} /$ year.

\section{Plant material}

The plant material is composed of an experimental plot named $\mathrm{Ci} 1 / 11 / 93$ divided into six blocks. This plot is composed of 94 genotypes among which, 34 genotypes of the Guinean group, 44 genotypes of the Congolese group and 16 hybrid genotypes between the Guinean and Congolese groups. All these genotypes were planted in 1993 in plot Ci1/11/93 isolated by an area of primary forest. For the study of flowering phenology, only block 1 was considered. The plant material in this block is composed of 62 
genotypes including 34 from the Congolese group or $55 \%, 25$ from the Guinean group or $44 \%$ and 3 Guinean-Congolese intergroup hybrids or $1 \%$ of the population.

\section{Plant material used for the phenology study}

Flowering phenology parameters were monitored on 139 trees out of the 276 trees in block 1 . The 139 are composed of 79 trees from 12 Guinean genotypes and 60 trees from 11 Congolese genotypes.

\section{Plant material used for the paternity study}

All 94 parental genotypes of 34 genotypes from the Guinean group, 44 genotypes from the Congolese group, and 16 hybrids genotypes from the cross between the Guinean and Congolese were considered for paternity analysis. The progenies are composed of 1361 seedlings obtained from open pollination of 69 mother trees in Block I. The paternity of the different genetic groups (Guinean, Congolese and hybrids) was determined and the contribution of the paternal parents in the progeny under open pollination conditions was evaluated (Table 1).

Table 1

Genotypes used for the study of phenology and paternity

\begin{tabular}{|lllll|}
\hline Study & Guinean relatives & Congolese relative & Hybrides relative & Total relative \\
\hline Phenology & $12[79]$ & $11[60]$ & & $23[139]$ \\
\hline Paternity & $34(501)$ & $44(656)$ & $1(202)$ & $79(1361)$ \\
\hline$\square:$ Number of plants per genetic pool & & \\
\hline $0:$ Number of offspring per genetic pool & & \\
\hline
\end{tabular}

\section{Phenology study}

In coffee plants under the climatic conditions of Côte-d'Ivoire, flowering is generally triggered by a rainfall of at least $10 \mathrm{~mm}$ (Louarn 1992) during the dry season, which extends from December to March in Côte d'Ivoire. The study of flowering phenology consisted of noting the time between the rainfall trigger and anthesis on the one hand, and evaluating the flowering intensity of the plants on the other, using the following rating scale:

- 0 : no flowering ;

- 1: very weak flowering (at least $20 \%$ of the crown covered with flowers, about ten);

- 2: weak (between 20 and $50 \%$ of the crown covered with flowers, about twenty);

- 3: medium (at least $50 \%$ of the crown covered with flowers). From this score, flowering is considered satisfactory (Maalouf et al. 2011);

- 4: abundant (between 50 and $80 \%$ of the crown covered with flowers); 
- 5: very abundant (more than $80 \%$ of the crown covered with flowers).

\section{Paternity study}

Discovering SNP markers through data mining

SNP data mining was performed using sequence data of 14 C. canephora genotypes which were deposited in the NCBI Sequence Read Archive (SRA) database. These SRA reads were downloaded from the database and mapped on the $C$. canephora reference genome (Denoeud et al. 2014) using BWA program. The Genome Analysis Toolkit (GATK) package v 3.520 was used for SNP calling using HaplotypeCaller with default parameter.

Then the hard filters (parameters: QD < 2.0 || FS > 60.0 || MQ < 40.0 || MQRankSum <-12.5 || ReadPosRankSum <-8.0) were applied to the filter low-quality alleles. To select high-quality SNPs for experimental validation, any SNPs that had other possible adjacent SNP sites $80 \mathrm{bp}$ upstream or $80 \mathrm{bp}$ downstream were eliminated. From the discovered putative SNPs, a subset of 288 putative SNPs was selected for validation test using the nanofluidic array genotyping system (Fluidigm Co, South San Francisco, CA). The primers of the selected 288 SNPs were designed by Fluidigm and applied on the selected jujube cultivars for validation. Based on the validation result, the top 200 SNPs with high repeatability were used for further analysis of genetic diversity. then the 90 most polymorphic SNPs were used for paternity analysis.

DNA isolation and SNP genotyping

SNP genotyping

DNA was isolated from 3 discs of dry leave collected from each tree in the field and each progeny seeding. SNP genotyping was performed at USDA-ARS, Sustainable Perennial Crops Lab, Beltsville, MD, USA, using the Fluidigm 96.96 Dynamic ArrayTM (Fluidigm, San Francisco, CA). Each 96.96 Dynamic Array can run 96 samples against 96 SNP assays generating a total of 9.216 data points in a single experiment. One key feature of this protocol is the inclusion of a specific targeted amplification (STA) reaction (Wang et al. 2009), which allows the enrichment of template molecules for each individual Integrated Fluidic Circuit ${ }^{\circledR}$ (IFC) reaction that facilitates the multiplexing during genotyping. An advantage to STA is that it allows the use of limited or low-quality DNA samples and reduces bias that may occur when samples are loaded to the 96 sample wells of the IFC. Since coffee leaf tissues contain high levels of polysaccharides and polyphenolic compounds that can potentially inhibit PCR amplification, the STA step was strongly recommended. The STA reaction was performed as described in the Fluidigm SNP Genotyping User Guide, PN 68000098 Rev I1 (Fluidigm 2013). The STA master mix consisted of $2.5 \mu \mathrm{L}$ of TaqMan ${ }^{\circledR}$ Taq polymerase (Life Technologies, Carlsbad, CA), PreAmp Master Mix $(2 \mathrm{X}), 1.25 \mu \mathrm{L}$ of Pooled assay mix (0.2X), and $1.25 \mu \mathrm{L}$ of genomic DNA for a total reaction volume of 5.0 $\mu \mathrm{L}$. 
PCR was performed with an initial denaturation step of $95^{\circ} \mathrm{C}$ for $10 \mathrm{~min}$, followed by 14 cycles of a 2-step amplification profile consisting of $15 \mathrm{sec}$ at $95^{\circ} \mathrm{C}$ and $4 \mathrm{~min}$ at $60^{\circ} \mathrm{C}$. The resulting amplified DNA was then diluted 1:5 in TE buffer in order to reduce the concentration of any remaining PCR by-products. Samples were then genotyped using the nanofluidic 96.96 Dynamic ArrayTM IFC (Integrated Fluidic Circuit; Fluidigm Corp.). The 96.96 Dynamic Array IFC for SNP genotyping was described by Wang et al. (2009). End-point fluorescent images of the 96.96 IFC were acquired on an EP1TM imager (Fluidigm Corp.). The data was recorded with Fluidigm Genotyping Analysis Software (Fluidigm, San Francisco, $\mathrm{CA})$.

\section{Data analysis}

Paternity analysis

CERVUS 3.0.6 software (Marshall et al. 1998, Kalinowski et al. 2007) was used to assign relatedness with SNPs genotype data. The method used is based on the maximum likelihood approach (Thompson 1976 and Meagher 1986). For each descendant, a measure of the probability that each potential father is the actual father is calculated as a logarithmic score LOD (logarithm of odds). In CERVUS, the male parents of each offspring are determined using the "sex unknown" option. The list of candidate parents is composed of all genotypes in the trial. Paired parent analysis was applied to assign the two parents of each individual. The female parent serves as a control for the applied test. In CERVUS, the proportion of input errors is used as the error rate in the likelihood calculation during the simulation that precedes the parent pair assignment operation. An error rate of $0.2 \%$ was used for this analysis. The simulation was done with 10,000 cycles of replicates with discount assuming that $80 \%$ of the potential parents were listed. The critical likelihood value (LOD score) was considered with a percentage of $95 \%$ in the strict sense and $80 \%$ in the broad sense during the simulation, respectively.

The contribution of a male progenitor or group of male progenitors to the pollination of a tree or group of trees in the plot is determined by the percentage of the number of paternal progenies observed for the tree or group of trees. The Mann-Whitney $U$ test was used to compare the contribution values of Guinean and Congolese progeny. This test was performed using the XLSAT 2014 software.

Phenology analysis

Flowering data were analyzed with $\mathrm{R} v 3.6 .2$ software. The normality of the data and the homogeneity of the Fisher variances were verified by the Shapiro-Wilk test (Shapiro and Wilk, 1965). Thus, non-parametric one-criteria classification tests were performed to compare the genetic groups and genotypes of canephora studied. For the twenty-three genotypes, the Kruskal-Wallis test was used and the WilcoxonMann-Whitney test for the 2 genetic groups. These tests allowed multiple comparison of means at the $5 \%$ threshold when significant differences were observed.

Pollen dispersal in the plot 
The distances between pollinated trees and pollinator trees are calculated by the Pythagore theorem. The relationship between the pollination distance and the importance of the contribution to pollination is estimated by linear regression.

\section{Results}

\section{Spreading of the flowering}

Flowering onset was synchronous between the Guinean and Congolese genetic groups over the four years of observation. However, analysis of the flowering spread curves shows a shift between the anthesis peaks of each group. Thus:

- In 2018, the peak of anthesis was observed on the 6 th day after which $54.43 \%$ of the trees flowered in the Guineans. The peak for the Congolese was observed on day 7 , with $81.96 \%$ of the trees flowering. From these two peaks, a continuous inflection of flowering in both genetic groups was observed until day 8 (Fig. 1a).

- In $2019,97.68 \%$ of the trees in the Guinean group flowered on day 6 , showing their peak anthesis. The peak anthesis of the Congolese trees was observed one day later with $51.66 \%$ of the trees flowering. From these two peaks, a progressive decrease in flowering of both genetic groups was observed until day 8 (Fig. 1b).

- Observations of the February 2020 flowering indicate that the peak of anthesis of the Guinean was reached on day 6 with $51.41 \%$. One day later, the peak of the Congolese group was reached with $59.32 \%$ of trees in bloom. A continuous inflection of flowering in both groups was observed on day 8 (Fig. 1c).

- In January 2021, the peak of anthesis of Guinean trees was observed on day 6 with $46.62 \%$ of trees in flower. The Congolese peak was observed 2 days later with $91.66 \%$ of trees in bloom. From these two peaks, a gradual decrease in flowering of the two genetic groups was observed until day 9 (Fig. 1d).

\section{Average flowering time in Guinean and Congolese coffee trees}

The results of the average flowering time recorded over these four years showed that there was a significant difference between the flowering of the Congolese and Guinean coffee groups after the onset of the first rainfall following the long dry period (Table 2). Thus, the Guinean genotypes flowered earlier on the 6th day after the first rainfall following the long dry season, while the Congolese cultivars flowered one or two days later on the 7th or 8th day in 2018, 2019 and 2021. However, observations in 2020 showed synchronized flowering of the two genetic groups on day 7. 
Table 2

Average values of flowering time in Guinean and Congolese genotypes during 2018, 2019, 2020 and 2021.

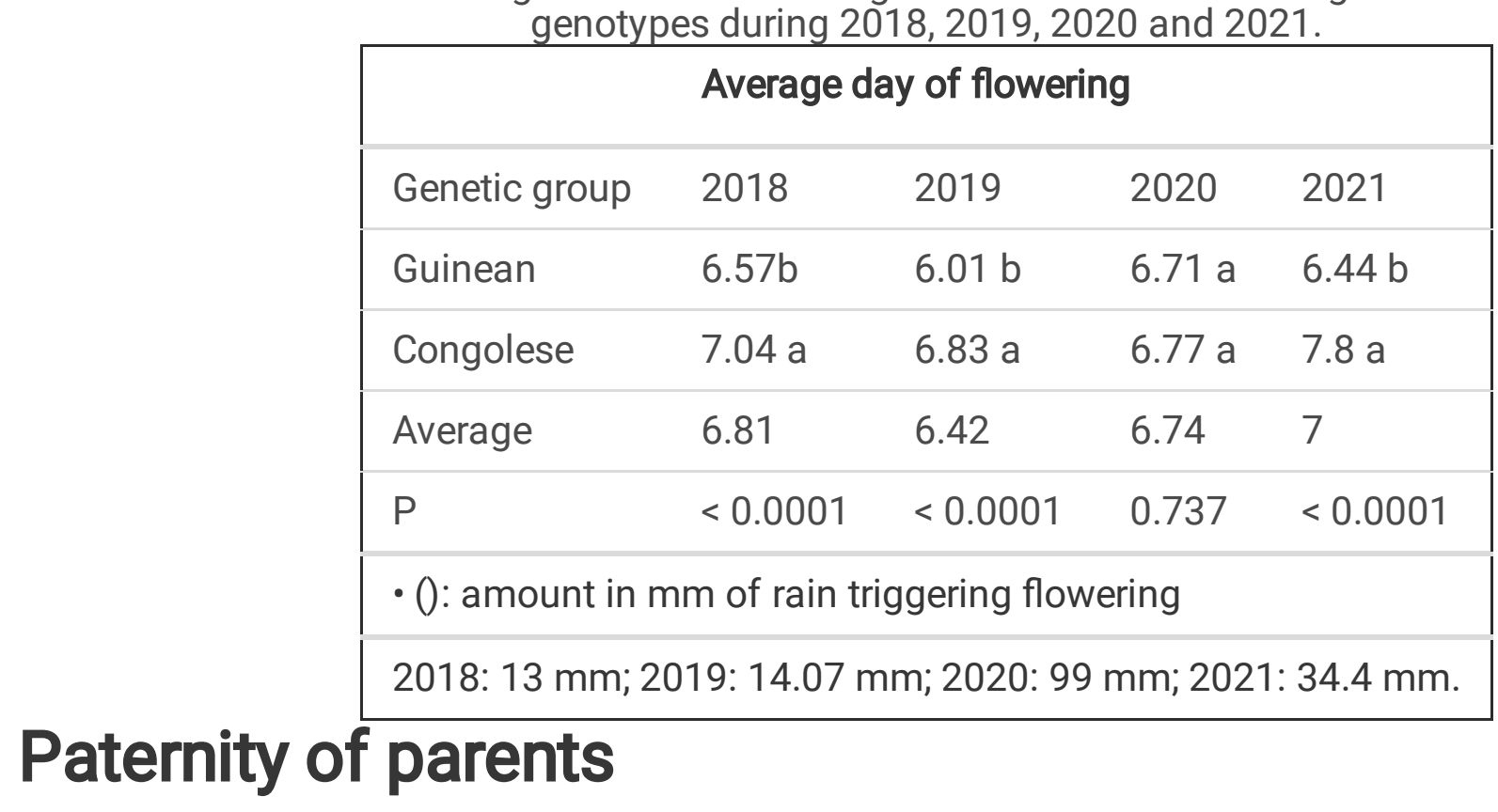

Paternal contributions in the descendants

After open pollination, progeny analysis revealed that Congolese sires were the major contributors to progeny with $48 \%$. Guinean progenitors contributed $37 \%$ of the progeny and hybrids contributed $15 \%$ (Fig. 2). In the free-living progeny, there were 501 plants of Guinean progenitors, 656 plants of Congolese progenitors and 202 plants of inter-group hybrid progenitors. Thus, there was a very significant increase $(p<0.001)$ in the proportion of intergroup hybrids in the progeny, from $1-15 \%$.

Contribution of Guinean, Congolese and hybrid male genotypes in the progeny of Guinean and Congolese feet

The sum of the contributions of the Guinean spawners to the Guinean broodstock set was $52 \%$ compared to $40 \%$ for the sum of the Congolese spawners (Fig. 3a). The Mann-Whitney test $(p=0.053)$ showed that there was no significant difference between the two proportions.

Among all Congolese mother plants, the sum of the contributions of Congolese broodstock was $58 \%$ compared to $18 \%$ for the sum of the contributions of Guinean mother plants (Fig. 3b). The Mann-Whitney test $(p=0.002)$ applied to the contributions of the Guinean and Congolese broodstock showed a significant difference.

Hybrids contributed significantly to the pollination of Congolese mother trees (24\%) and less so to Guinean mother trees (8\%). Thus, the hybrids appear to be more compatible with the Congolese than with the Guineans.

Average individual contribution of Congolese, Guinean and hybrid progenitors to the progeny of Congolese and Guinean mother plants 
The average individual contribution of the progenitors to the progeny of the genetic groups is shown in Fig. 4, ranging from 0 to $5.1 \%$ in the Guinean mother trees and from 0 to $4.5 \%$ in the Congolese mother trees. A first group of trees with a low contribution between 0 and $1 \%$ can be seen. This group represents $43.52 \%$ of the trees that made a low contribution to the pollination of female trees. An identical proportion of $43.52 \%$ shows a contribution between 1 and $3 \%$. Finally, $12.94 \%$ of the trees are 'superpollinators' that show a contribution higher than $3 \%$ and between 3 and $6 \%$.

Pollen dispersal in the plot

The pollen dispersal results show that the pollen spread distance of the trees is between 2 and $94.13 \mathrm{~m}$ (Table 3). The maximum dispersal distance of allopollen, which is 94.13 in block 1 of the plot, is comparable to the diagonal of block 1 of the plot which is $101 \mathrm{~m}$. Thus, the size of the plot could not be a limiting factor for gene exchange between trees. It also allowed us to understand that tree pollination occurs in several directions. No direction, including wind direction, seems to affect pollination (Fig. 5). At the same time, a very weak positive linear regression was found between the contribution of male spawners and the distance between mother plants (Fig. 6). 
Table 3

Minimum and maximum distance of pollen dispersal

\begin{tabular}{|c|c|c|}
\hline Offspring & $\begin{array}{l}\text { Minimum distance of pollen dispersal } \\
(\mathrm{m})\end{array}$ & $\begin{array}{l}\text { Maximum distance of pollen dispersal } \\
(\mathrm{m})\end{array}$ \\
\hline 8821 L2 A3 & 2 & 94,13 \\
\hline $\begin{array}{l}8183 \text { L26 } \\
\text { A15 }\end{array}$ & 2 & 42,57 \\
\hline 8293 L7 A7 & 2 & 72 \\
\hline 8245 L9 A9 & 4 & 76 \\
\hline 8069 L49 A3 & 3,16 & 90,75 \\
\hline 8583 L9 A3 & 2,23 & 76 \\
\hline 8668 L31 A4 & 8 & 60,03 \\
\hline $\begin{array}{l}8518\llcorner 47 \\
\text { A13 }\end{array}$ & 4 & 88 \\
\hline 9477 L44 A5 & 3 & 80 \\
\hline $\begin{array}{l}8189 \text { L42 } \\
\text { A13 }\end{array}$ & 6 & 80 \\
\hline $\begin{array}{l}8159 \text { L30 } \\
\text { A12 }\end{array}$ & 4,12 & 58,13 \\
\hline 8410 L29 A6 & 2 & 54 \\
\hline 8056 L37 A7 & 11,18 & 62,9 \\
\hline 8464 L19 A3 & 2 & 60,2 \\
\hline 8411 L3 A6 & 2 & 88 \\
\hline 8121 L5 A14 & 4 & 90,19 \\
\hline $\begin{array}{l}8105 \text { L18 } \\
\text { A15 }\end{array}$ & 2 & 62,39 \\
\hline 8214 L21 A7 & 2 & 56 \\
\hline $\begin{array}{l}8387 \text { L25 } \\
\text { A10 }\end{array}$ & 4,12 & 54,62 \\
\hline 8477 L27 A3 & 2 & 52,95 \\
\hline 8416 L43 A2 & 10 & 82,93 \\
\hline $\begin{array}{l}8159 \text { L45 } \\
\text { A14 }\end{array}$ & 8,48 & 78,10 \\
\hline 8392 L50 A7 & 1,41 & 90,13 \\
\hline
\end{tabular}




\section{Discussion}

Gene flow between genetic groups of the same species plays a major role in the spatial organization of genetic diversity and is a major evolutionary force (Futuyama 1998). In plants, gene flow results from two major mechanisms, pollination and seed dispersal.

This study contributes to the analysis of gene flow between two genetically distant populations of the same species (C. canephora) (Guinean and Congolese) that co-exist in the same plot. In the case of the two genetic groups studied here, this is particularly relevant because these two groups are known to flower at different dates (Anthony 1992; Louarn 1992 and Akaffou 2013). Our study shows differences between the flowering peaks of the Guinean and Congolese genetic groups in the years 2018, 2019, 2020 and 2021. The anthesis period of a species or hybrid is the day when more than $50 \%$ of individuals flower (Maalouf et al. 2011). We observed a flowering lag between the Guinean and Congolese genetic groups with an earliness of the Guineans and a tardiness of the Congolese of about 1 day. Our results are consistent with those of Berthaud (1986) and Leroy et al. (1993). However, this time lag seems to vary according to the year. In 2020, this time lag does not exist.

The genetic mixing study was conducted on 1361 offspring during 2018, or the average lag between the two groups was greater than $1 / 2$ day. Despite this flowering lag, genetic mixing was observed between the two genetic groups. Our results revealed an increase in the number of hybrids (from $1 \%$ in the parental population to $15 \%$ in the progeny). This increase is accompanied by a $7 \%$ reduction in the frequency of Congolese (55 to $48 \%$ ) and Guineans (44 to $37 \%$ ). The significant increase in the frequency of hybrids is evidence of inter-group mixing. This inter-group mixing seems to depend mainly on a small number of progenitors (about $12.94 \%$ ) that contributed to more than $28 \%$ of the pollinations. We have verified that these "super-spawners" interbreed more with Guineans (19\%) than with Congolese (9\%) and this even when they are Congolese. This imbalance in the contribution of spawners does not seem to be related to their position in the plot. It does not seem to be clearly related to the number of plants either. For example, the Guinean "super-spawner" 789 is represented only once in the plot.

Assuming that the integrity of the concomitant genetic groups would be maintained, the pollen involved in the fertilization of both groups would have to come exclusively $(100 \%)$ from the same group. We show in this study that this is not the case. The anthesis mismatch is not a sufficient barrier for crosspollination. Paternity analyses showed that the contribution of Guinean and Congolese progenitors in the progeny of Guinean mother trees are equivalent. However, in the progeny of the Congolese mother trees, the contribution of the Congolese gene pool is much greater than that of the Guinean pool (Fig. 3). These differences can be explained by several factors including the founder effect, genetic erosion in the Guinean gene pool (endemic to Ivory Coast) and the type of data generated by the different markers used in this study. On the other hand, preferential fathers were also found for the mother coffee plants of the different genetic groups. This would be the consequence of gametophyte incompatibilities between certain genotypes (Berthaud 1986; Coulibaly 2002), discrepancies between flowering periods (Berthaud 1986; Leroy et al. 1993) and the viability of the pollen produced by each progenitor. Furthermore, the 
introduction of genotypes from the Congolese pool into coffee populations in Ivory Coast most likely represents an evolutionary force. This is supported by the increase of (1-15\%) hybrids in the progeny population. This increase is facilitated by gene flow through pollen (Berthaud 1984). Gene flow from these domesticated crops to wild Guinean species represents a threat to the genetic integrity of the Guinean pool. Our results therefore confirm the preliminary findings of Montagnon et al. 1993. Indeed, repeated occurrences of hybridization can lead to the loss of genetic integrity of the wild species, which becomes assimilated to the cultivar (Aerts et al. 2013). Therefore, to conserve the integrity and genetic diversity of the Guinean pool, in situ and ex situ conservation strategies are essential.

\section{Conclusion And Recommendations}

The success of Ivorian coffee growing is largely due to the introduction of the Congolese pool. This pool naturally hybridized with endemic Guinean coffee trees in Ivory Coast to form fertile and sometimes very productive intergroup hybrids that were empirically selected by breeders. However, in addition to deforestation, bush fires and climate change, the massive introduction of genes from the Congolese could have consequences for the maintenance of the genetic integrity of wild coffee trees representing the endemic Guinean group in Ivory Coast. Indeed, in our system, flowering time differences between the two groups do not constitute a sufficient barrier to prevent massive hybridization. It is important to verify if this contamination is already present in the wild coffee trees of Ivory Coast. It is also necessary to verify that seeds could not have been dispersed by wildlife in the forests hosting the Guinean genetic resources. And finally, a comprehensive assessment of existing germplasm should be undertaken, based on which a comprehensive conservation strategy should be developed that includes both in situ and ex situ conservation and addresses the need for duplication of germplasm in multiple locations.

\section{Declarations}

\section{Data archiving statement}

Data presented in this study can be found in online repositories. The name of repository and accessions number(s) can be found below

https://tropgenedb.cirad.fr/tropgene/JSP/interface.jsp?module=COFFEE

\section{Ethical Responsibilities of Authors}

We declare that this manuscript is original, has not been published before and is not currently being considered for publication elsewhere in any form or language (partially or in full). We ensure that there is no conflicts of interest associated with this publication, and there has been no significant financial support for this work that could have influenced its outcome.

All the authors are contributed as follow: 
Gnapi Diane Estelle: executed the experiment, collected field data;

Désiré N’Da Pokou: designed the experiment, supervised the experiment.

Hyacinthe Legnaté: Designed the experiment, supervise the field data collection;

Doffou Sélastique Akaffou: reviewed;

Zhang Dapeng: generated the molecular data, write and reviewed;

Kouamé Cyrille Koffi: analyzed the molecular data and Review;

Benoît Bertrand: Analyzed the data (field and molecular), write and reviewed;

Christophe Montagnon: Analyzed the data (field and molecular), edit and write

Simon-Pierre Assonvo N'Guetta: supervised the work

Manuscript has been read and approved for submission by all the authors.

\section{References}

Akaffou DS (2013) Étude et cartographie génétique du croisement Coffea pseudozanguebariae BRIDSON $X$ Coffea canephora PIERRE. Thèse de Doctorat d'état en sciences naturelles, spécialité : Génétique et Amélioration des plantes ; Soutenue à l'Université Nangui Abrogoua (Côte d'Ivoire) 146 p.

\section{Aerts R, Berecha G, Gijbels P, Hundera K, Van Glabeke S, Vandepitte K \& Honnay 0 (2013) Genetic} variation and risks of introgression in the wild $\mathrm{C}$ offea arabica gene pool in south-western $\mathrm{E}$ thiopian montane rainforests. Evolutionary Applications, 6(2), 243-252.

Berthaud J (1984) Les ressources génétiques pour l'amélioration des caféiers africains diploïdes : évaluation de la richesse génétique des populations sylvestres et de ses mécanismes organisateurs. Conséquences pour l'application. PhD thesis, Université de Paris-Sud, Orsay, France. Available at http://www.documentation.ird.fr/hor/fdi:16623 [accessed 7 Nov. 2017].

Berthaud J (1986) Les ressources génétiques pour l'amélioration des caféiers africains diploïdes : évaluation de la richesse génétique des populations sylvestres et de ses mécanismes organisateurs. Conséquences pour l'application. Travaux et documents de I'ORSTOM, 188, 379 p.

Bunn C, Läderach P, Ovalle Rivera O, Kirschke D (2015) A bitter cup : climate change profile of global production of Arabica and Robusta coffee. Climatic Change 129(1-2): 89-101. https://doi. org/10.1007/s10584-014-1306-x

Brou YT, Servat E, Paturel JE (2000) Évolution du couvert forestier ivoirien sur la période 1950-1990, en relation avec la variabilité du climat et les activités anthropiques. In : Servant M., Servant-Vildary S. (eds) 
Dynamique à long terme des écosystèmes forestiers intertropicaux : 57-62. Paris, IRD, UNESCO.

Coste R. (1989) Caféiers et cafés. Paris, France, G P Maisonneuve et Larose, 373 p.

Coulibaly I, Noirot M, Lorieux M, Charrier A, Hamon S et Louarn J (2002) "Introgression of selfcompatibility from Coffea heterocalyx to the cultivated species Coffea canephora." Theor Appl Genet 105(6-7): 994-999.

Davis AP, Govaerts R, Bridson DM, Stoffelen P (2006) An annotated taxonomic conspectus of the genus Coffea (Rubiaceae). Bot J Linn Soc 152(4) :465-512.

Davis AP, Tosh J, Ruch N \& Fay MF (2011) Growing coffee : Psilanthus (Rubiaceae) subsumed on the basis of molecular and morphological data ; implications for the size, morphology, distribution and evolutionary history of Coffea. Botanical Journal of the Linnean Society, 167(4), 357-377.

Devreux M, Vallaeys G, Pochet P, Gilles A (1959) Recherches sur l'autostérilité du caféier robusta (Coffea canephora Pierre). Bruxelles, Publications de l'Institut National pour l'Étude Agronomique du Congo Belge (INEAC).

Denoeud F, Carretero-Paulet L, Dereeper A, Droc G, Guyot R, Pietrella M, ... \& Lashermes P (2014) The coffee genome provides insight into the convergent evolution of caffeine biosynthesis. Science, 345(6201), 1181-1184.

Eskes AB, Leroy T (2012) Coffee selection and breeding. In: Wintgens J.N. (ed.) Coffee: growing, processing, sustainable production: a guidebook for growers, processors, traders, and researchers: 6190. Weinheim, Germany, Wiley-VCH Verlag GmbH \& Co. KGaA.

FAOSTAT (2018) Food and Agriculture Organization of the Unite Nations, Statistics Division. Available online at : http://faostat.fao.org/

FAOSTAT (2019) Culture. http://www.fao.org/faostat/fr/\#data/QC, consulté le 21/03/2019.

Futuyma D. J. (1998) Evolutionary Biology (3rd ed.). Sunderland, MA : Sinauer Associates.

Fluidigm (2013) Fluidigm ${ }^{\circledR}$ SNP genotyping analysis software user guide. Rev 11, PN 68000098, South San Francisco, CA, Fluidigm Corporation https://wwwmsciencecomau/upload/pages/ fluidigmtech/fluidigm-snp-genotyping-user-guide-151112pdf. Accessed 10 July 2021

Gomez C, Dussert S, Hamon P, Hamon S, de Kochko A, Poncet V (2009) Current genetic differentiation of Coffea canephora Pierre ex A Froehn in the Guineo-Congolian African zone : cumulative impact of ancient climatic changes and recent human activities. BMC. Evolution biol 9: 167-185.

ICO (2018) Coffee market report. October 2018. International Coffee Organization. Available at http://www.ico.org/documents/ cy2018-19/cmr-1018-e.pdf [accessed 28 Nov. 2018]. 
Kalinowski ST, Taper ML, Marshall TC (2007) Revising how the computer program CERVUS accommodates genotyping error increases success in paternity assignment. Molecular Ecology, 16, 1099-1106.

Kassin KE, Doffangui K, Kouamé B, Yoro RG \& Assa A (2008) Variabilité pluviométrique et perspectives pour la replantation cacaoyère dans le Centre Ouest de la Côte d'Ivoire. Journal of Applied Biosciences, 12: $633-641$.

Labouisse JP, Curby P, Austerlitzs, Rivallan R, Nguyen HA (2020) New insights on spatial genetic structure and diversity of Coffea canephora (Rubiaceae) in Upper Guinea based on old herbaria. Plant Ecology and Evolution 153 (1): 82-100 https://doi.org/10.5091/plecevo.2020.1584

Leroy T, Montagnon C, Charrier A et Eskes AB (1993) "Reciprocal recurrent selection applied to Coffea canephora Pierre. I. Characterization and evaluation of breeding populations and value of intergroup hybrids." Euphytica 67(1-2) : 113-125.

Leroy T, Montagnon C, Cilas C, Yapo A, Charmettant P \& Eskes AB (1997) Reciprocal recurrent selection applied to Coffea canephora Pierre. III. Genetic gains and results of first intergroups crosses. Euphytica 95 : 347-354pp.

Louarn J (1992) La fertilité des hybrides interspécifiques et les relations génomiques entre caféiers diploïdes d'origine africaine (Genre Coffea L. sous-genre Coffea). Montpellier, France, Montpellier II, Sciences et Techniques du Languedoc : 135.

Maalouf F, Khalil S, Ahmed S, Akintunde AN, Kharrat M, Shama'a KE, Hajjar S, Malhotra RS (2011) Yield stability of faba bean lines under diverse broomrape prone production environments. Field Crops Res 124: $288-294$.

Marshall TC, Slate J, Kruuk BE, Pemberton (1998) Statistical confidence for likelihood-based paternity inference in natural populations. Molecular Ecology, 7: 639-655.

Meagher TR (1986) Analysis of paternity within a natural population of Chamaelirium luteum. I. Identification of most-likely male parents. American Naturalist, 128, 199-215.

Montagnon C, Leroy T, Yapo A, (1992) Diversité génotypique et phénotypique de quelques groupes de caféiers (Coffea canephora Pierre) en collection. Conséquence sur leur utilisation en sélection Café Cacao Thé. 36 (3) : 187-198 pp.

Montagnon C, Leroy T, Yapo A (1992b) Etude complémentaire de la diversité génotypique et phénotypique des caféiers de l'espèce Coffea canephora en collection en Côte d'Ivoire. XIVè Colloque Scientifique International sur le Café, San Francisco (USA), ASIC : 444-450.

Montagnon, C., Leroy, T., \& Yapo, A. (1993) Caractérisation et évaluation de caféiers Coffea canephora prospectés dans des plantations de Côte-d'Ivoire. Café, Cacao, Thé, 37:115-119. 
Montagnon C. (2000) Optimisation des gains génétiques dans le schéma de sélection récurrente réciproque de Coffea canephora Pierre. Ecole Nationale Supérieure Agronomique de Montpellier, Thèse de Doctorat $118 \mathrm{p}$.

Montagnon C, Leroy T, Cilas C, Legnaté H, \& Charrier A (2008) Heterozygous genotypes are efficient testers for assessing between-population combining ability in the reciprocal recurrent selection of Coffea canephora. Euphytica, 160(1), 101-110.

N'Guessan KJC (2017) Comportements, dynamiques et équilibres des cations majeurs et de certains oligo-éléments dans les sols cacao cultivés de Côte d'Ivoire. Thèse, Université Félix Houphouët Boigny, $141 \mathrm{p}$.

Oddou-Muratorio S, Klein EK, Vendramin G, Fady B (2011) Spatial vs. Temporal effects on demographic and genetic structures: the roles of dispersal, masting and differential mortality on patterns of recruitment in Fagus sylvatica. Molecular Ecology 20 : 1997-2010.

Sagnard F, Oddou-Muratorio S, Pichot C, Vendramin GG, Fady B (2011) Effects of seed dispersal, adult tree and seedling density on the spatial genetic structure of regeneration at fine temporal and spatial scales. Tree Genetics \& Genomes 7: 37-48.

Shapiro SS \& Wilk MB (1965). An analysis of variance test for normality (complete samples). Biometrika, 52(3/4), 591-611.

Thompson E (1976) Inference of genealogical structure. Social science information, 15: 477-526.

Van Der Vossen H (2016). Narrowing the Yield Gap of Smallholder coffee Production as Sustainable Strategy to Meet Rising Demand for Quality Coffees. The programme and abstracts of the 26th International Conference on Coffee Science. November 13rd-17th 2016, Kunming, China, 382 p.

Wang J, Lin M, Crenshaw A, et al. 2009. High-throughput single nucleotide polymorphism genotyping using nanofluidic Dynamic Arrays. BMC Genomics; 10: 561.

\section{Figures}



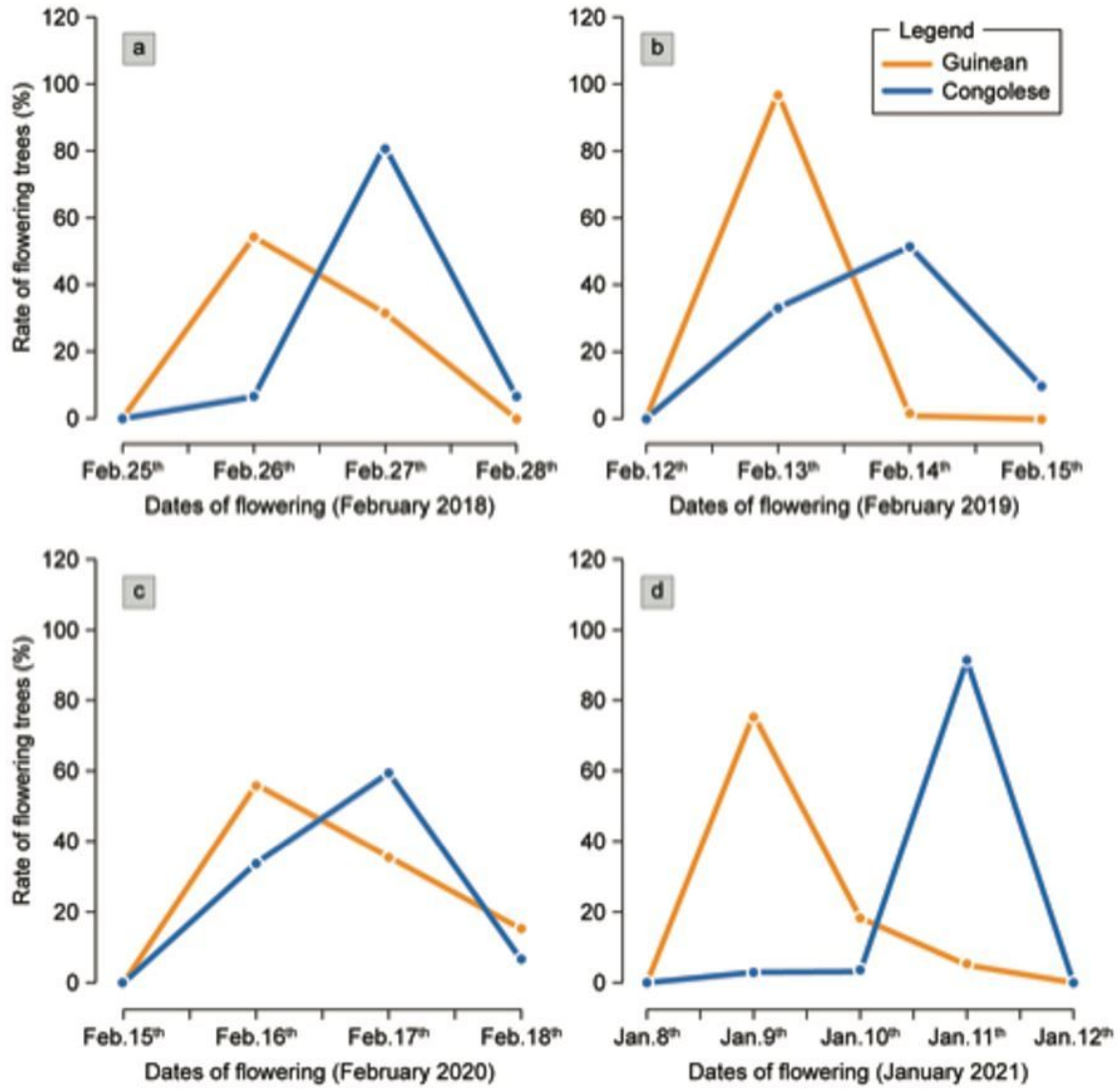

Figure 1

Flowering spread of all trees studied in Block I in February 2018, February 2019, February 2020 and February 2021. Made using Excel 


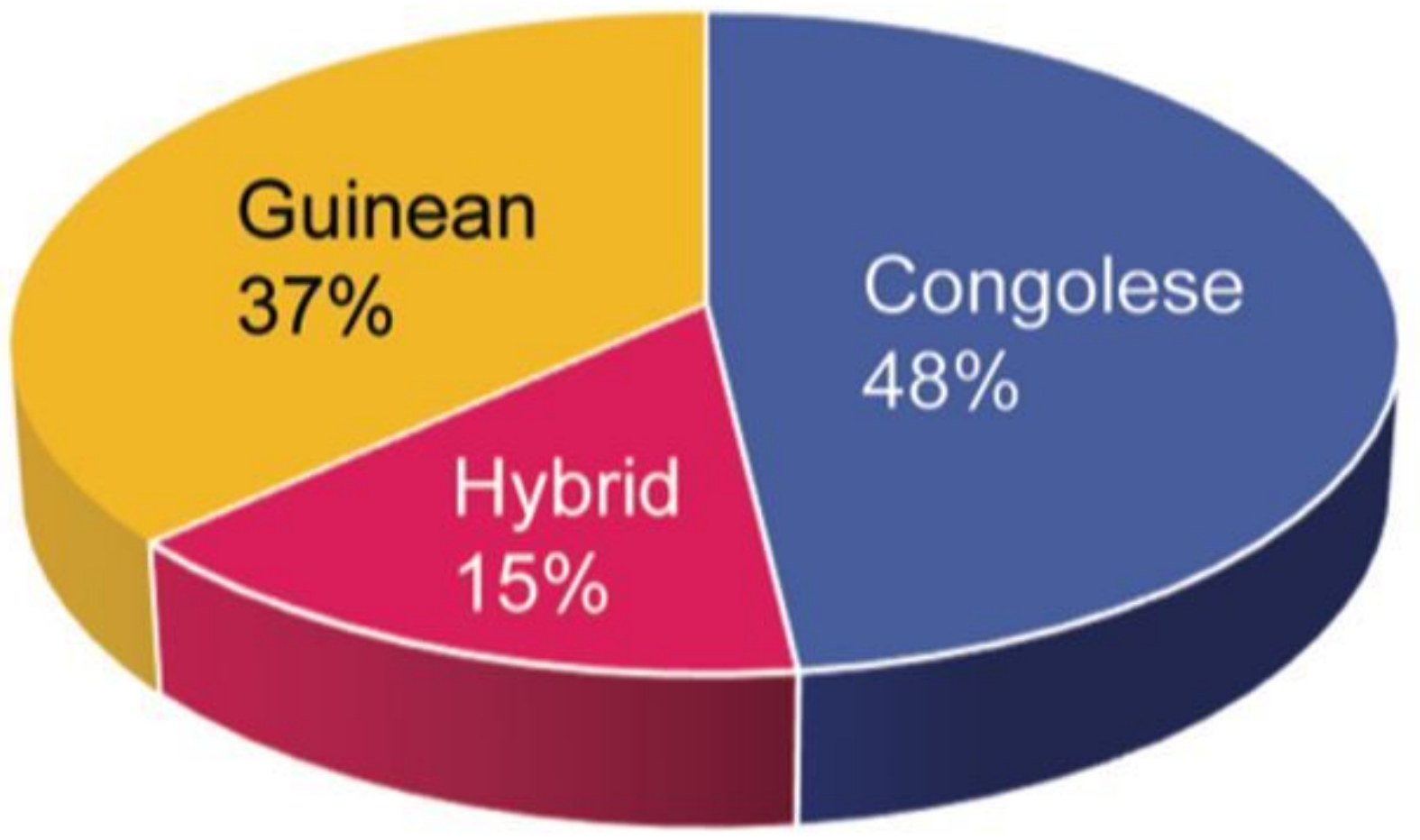

Figure 2

Paternal contribution of genetic groups in the offspring

a

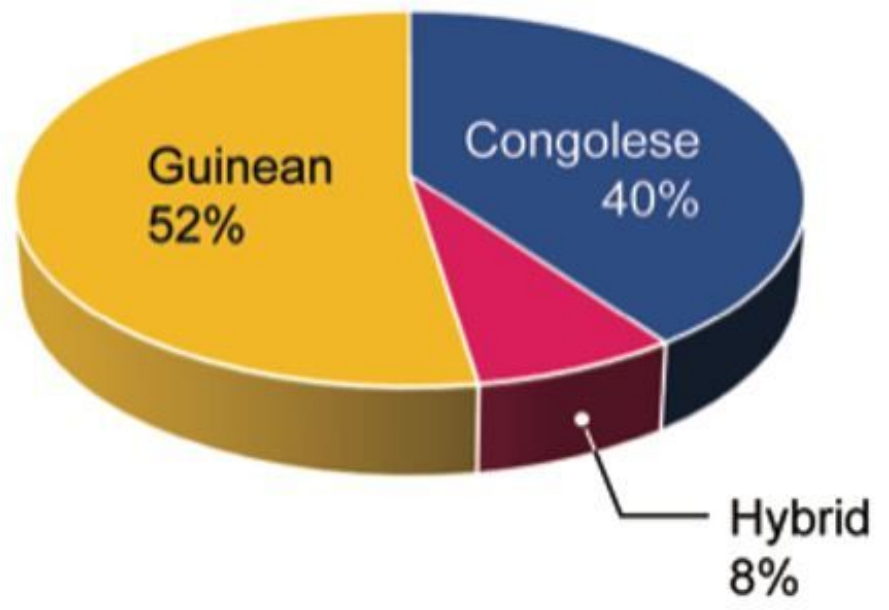

b

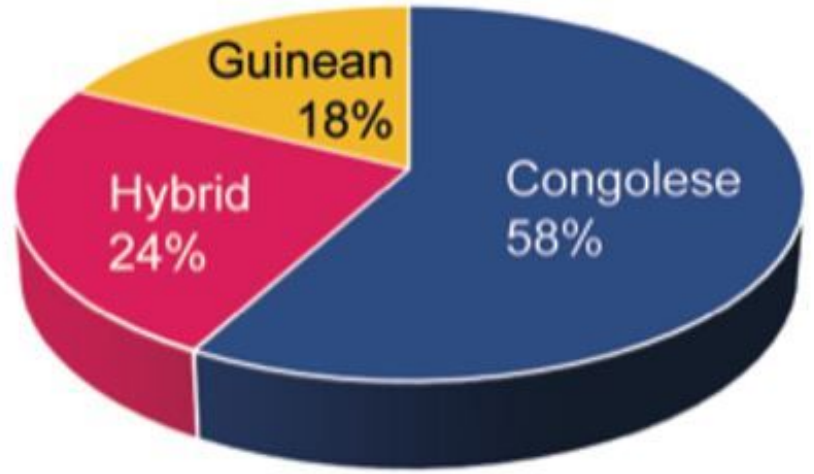

\section{Figure 3}

a: Contribution of Congolese, Guinean and hybrid progenitors to the progeny of Guinean mother plants; $b$ : Contribution of Congolese, Guinean and hybrid progenitors to the progeny of Congolese parent plants 


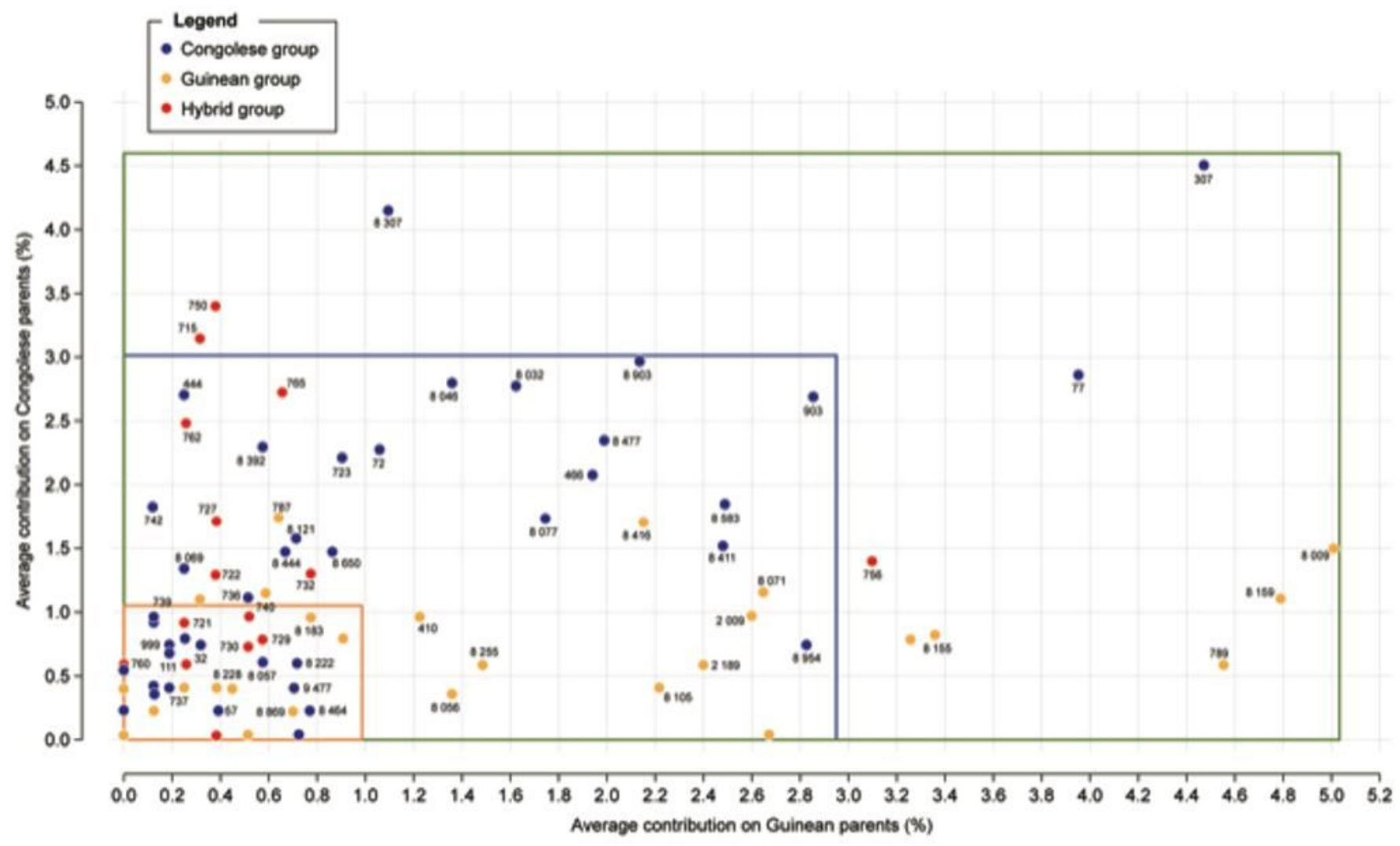

Figure 4

Scatterplot of the average contribution of Congolese (blue), Guinean (orange), and hybrid (red) male broodstock on the maternal trees. The small square indicates low-contributing broodstock [0-1\%], the next square indicates broodstock with a contribution of 1-3\%, and the largest square indicates broodstock that contributed the most to the pollination of female trees [3-5\%]. Made by Excel 


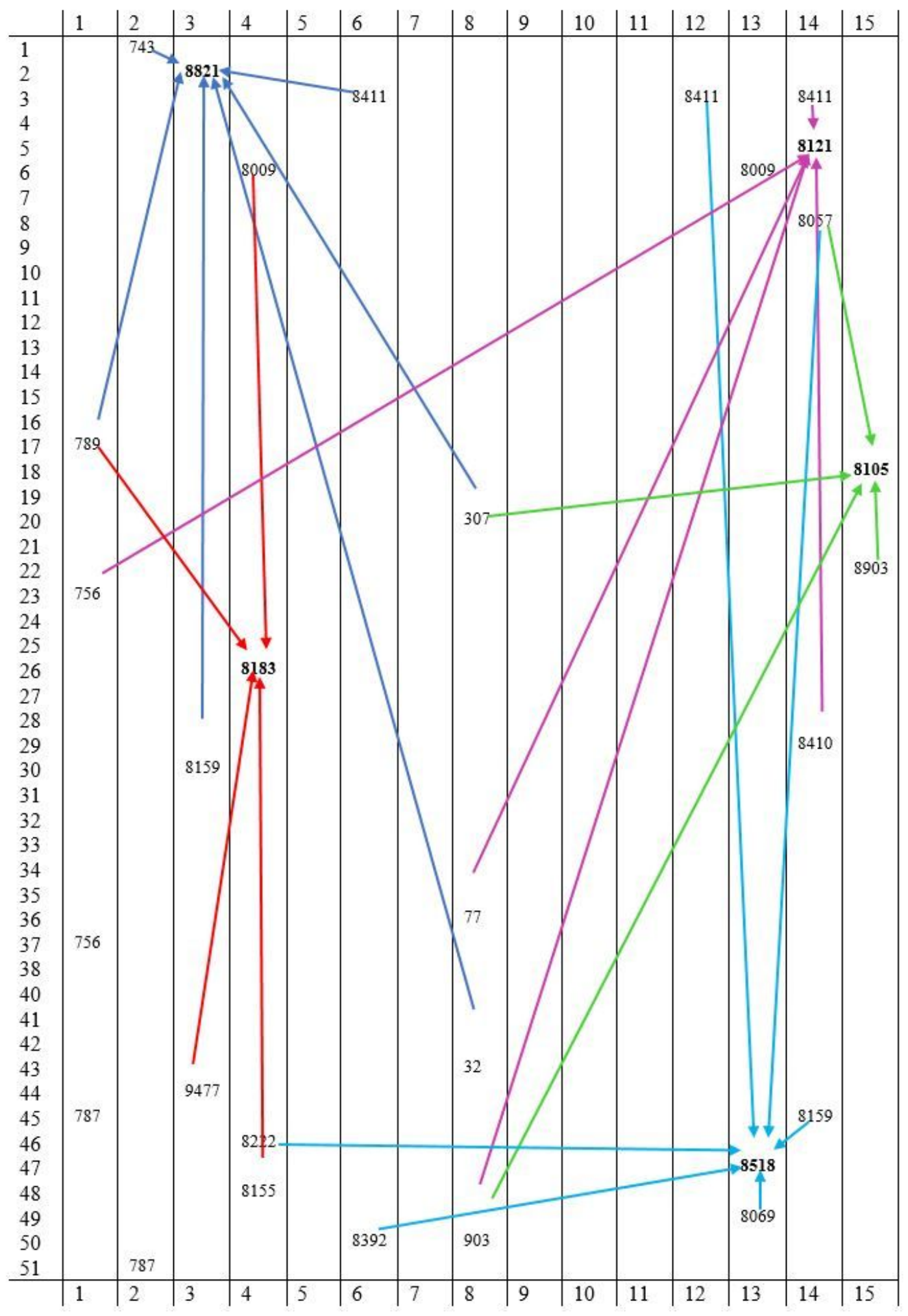

Figure 5

Pollen dispersal in the plot Made by Excel 

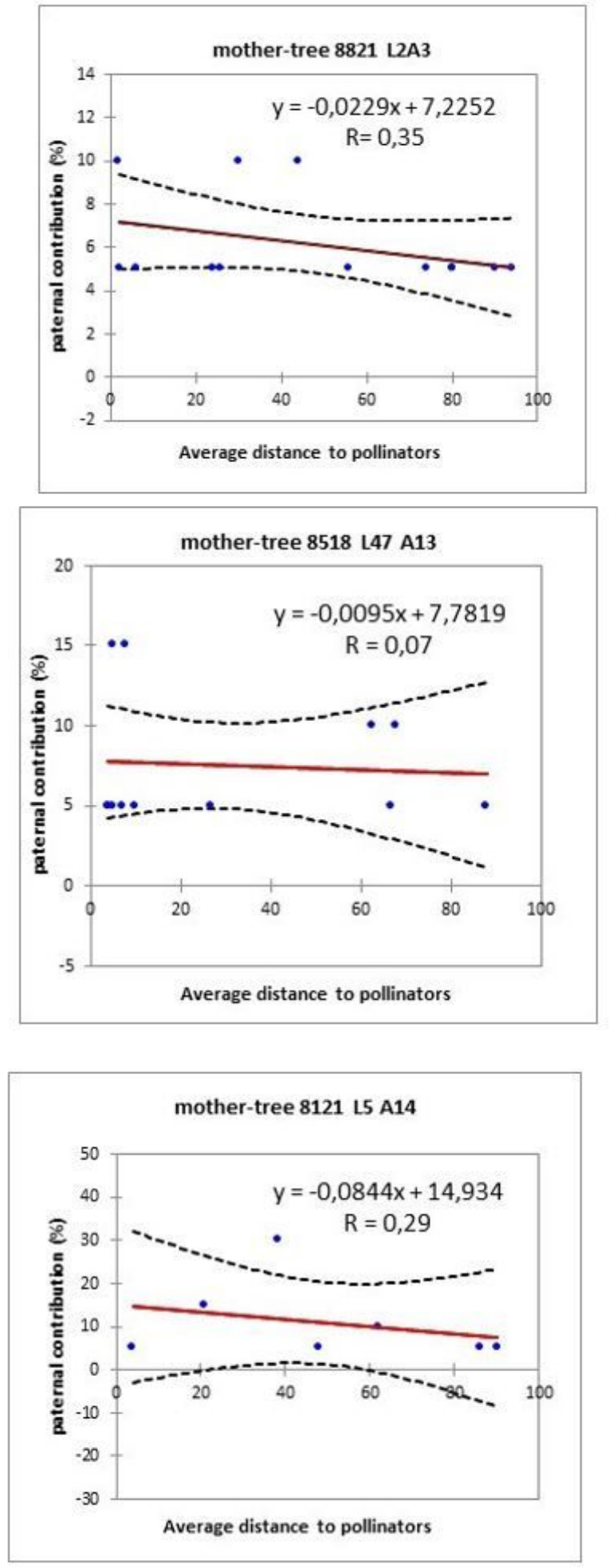
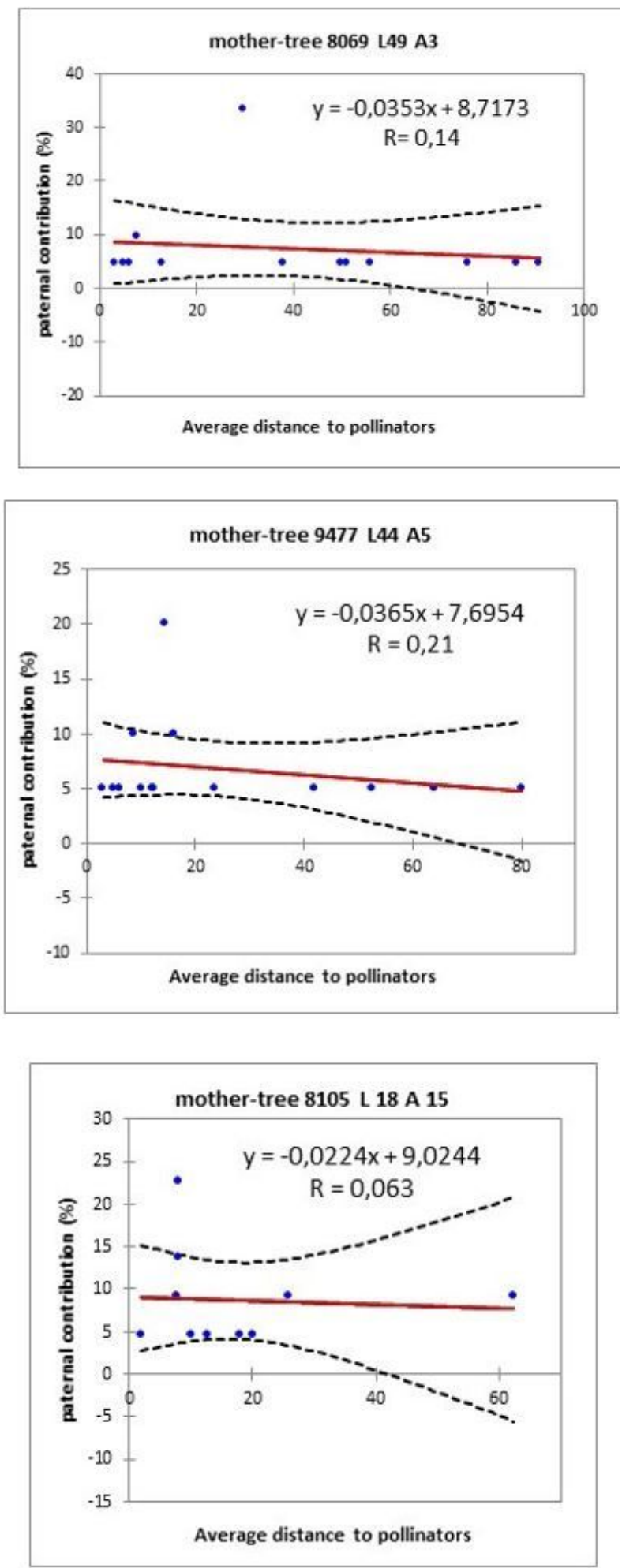

\section{Figure 6}

Relationship between paternal contribution and pollinators distance Made by XLSAT 2014

\section{Supplementary Files}

This is a list of supplementary files associated with this preprint. Click to download. 
- suplementryfilecoffee.docx 